\title{
Uncharacterized Protein C5orf67
}

National Cancer Institute

\section{Source}

National Cancer Institute. Uncharacterized Protein C5orf67. NCI Thesaurus. Code C140144.

Uncharacterized protein C10orf107 (208 aa, 24 kDa) is encoded by the human C10orf107 gene. This protein may play a role in blood pressure regulation. 